Proc. Estonian Acad. Sci. Geol., 1992, 41, 4, 215-224

UDC 551.733.3:56.016(474)

Viiu NESTOR*

\title{
CHITINOZOAN DIVERSITY DYNAMICS IN THE EAST BALTIC SILURIAN
}

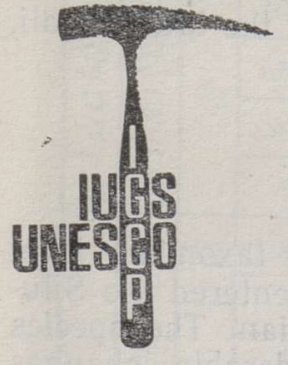

Project 216

Global Bioevents

\begin{abstract}
The species diversity of chitinozoans has undergone considerable changes throughout the East Baltic Silurian. Wellpronounced diversity maxima occur in the sedgwickii, murchisoni bohemicus, testis, and formosus zones and in the middle Pridoli; innovation maxima fall in the turriculatus, flexilis, radians, scanicus, and formosus zones. The major extinction events took place in the sedgwickii, riccartonensis, testis, and balticus zones. Most of these events were closely related to the transgression-regression phases of the Silurian Baltic Basin, global sea-level fluctuations, and evolutionary changes in the chitinozoan assemblage.
\end{abstract}

\section{Introduction}

During the Silurian the East Baltic cratonic basin was subjected to almost continuous sedimentation. In the geological record four major sedimentological cycles have been distinguished (Kaljo, 1971; Эйнасто, 1986), closely related to the sea-level changes, but also to the evolution and fluctuations in the relative abundance and diversity of chitinozoans. In this work attempts have been made to outline the character and general trends in chitinozoan dynamics in the Silurian sequence, which contains rich assemblages of over 150 species, most of them widely distributed all over the world. The curves showing the number of chitinozoan species in the Baltic Silurian are based on the samples studied from the Ikla (lower and middle Llandovery), Ohesaare (upper Llandovery, upper Ludlow and Pridoli), and Ventspils cores (middle and upper Wenlock and lower Ludlow). These sections and intervals were chosen as they show the co-occurrence of chitinozoans and graptolites (see Кальо, 1970; Ульст, 1987; Nestor, 1990), permitting to integrate directly the chitinozoan zonation and biotic events with the graptolite scale (Fig. 1). In all charts data are plotted in the middle of the graptolite zones.

Using published data, similar curves as for the East Baltic have tentatively been compiled also for the Welsh Basin (Dorning, 1981) and Palencia, North Spain (Schweineberg, 1987) (Figs. 2-5).

\section{Geological Setting}

The transgressive phase of the first main sedimentation cycle in the early and middle Llandovery was characterized by the rhythmically alternating accumulation of calcareous and terrigenous muds. It was followed by a rapid regression that reached the maximum in the convolutus Biozone. The second cycle began with a transgressive phase in the sedgwickii Zone and was characterized by the relative stability in sedimentation in the late Llandovery and early Wenlock, when argillaceous

\footnotetext{
* Eesti Teaduste Akadeemia Geoloogia Instituut (Institute of Geology, Estonian Acad-
} emy of Sciences), Estonia pst. 7, EE0105 Tallinn. Estonia. 
deposits covered large areas. Intensive regression followed at the end of the Wenlock (Nestor and Nestor, 1991), but in the deeper, middle part of the basin (Ventspils area) it was weakly expressed. The third cycle began with a transgressive phase in the lowermost Ludlow, when calcareous mudstones and marls accumulated. It was succeeded by a regression in the middle Ludlow, at the tauragensis Zone level, during which calcareous deposits began to form in the central part of the basin, terminating the graptolite succession in the East Baltic (see Ульст, 1987). The transgressive phase of the last cycle, which started in the late Ludlow, reached its maximum in the middle Pridoli. This phase was characterized by intense influx of terrigenous material and deposition of calcareous marls over a vast area. The cycle lasted until the late Pridoli, up to the final Silurian regression.

\section{Event Patterns}

The evolution of the Silurian Chitinozoa on the higher taxonomic level (genera, families) was rather slow. Most of the genera entered the Silurian from the Ordovician and continued in the Devonian. The species diversity of chitinozoans, however, underwent considerable changes throughout the Silurian, enabling to trace several bioevents of different scales. They reflect general tendencies in the evolution, but are also dependent on the sea-level changes and the water chemistry.

The diversity curve of the East Baltic Silurian chitinozoans (Fig. 2) shows four well-pronounced peaks and one modest peak for the confertus and cyphus zones. This first early Llandovery diversity maximum was followed by a steady decline in the diversity, lasting up to the short-time radiation in the sedgroickii Zone, which coincided with the beginning of the second main transgressive phase in the East Baltic Silurian. The third diversity maximum occurred at the murchisoni bohemicus Zone level and was followed by a major extinction event in the riccartonensis Zone (Fig. 4). A new radiation maximum was attained in the testis Zone, followed by another mass extinction event at the same level. The last Silurian radiation began in the early Ludlow scanicus Zone and, continuously increasing, extended up to the middle Pridoli. The most significant late Silurian chitinozoan extinction event occurred in the balticus Zone. Similarly to the riccartonensis Zone, it was characterized by the disappearance of more than $75 \%$ of the occurring species.

The bioevents which are more closely related to the evolutionary changes of chitinozoans are demonstrated in the innovation curve (Fig. 3 ). The most important innovation events occur at the base of the Silurian and within the sedgwickii, turriculatus, flexilis, radians, scanicus, and formosus zones, showing renewal of more than $50 \%$ of the species. A very high innovation peak characterizes the turriculatus Zone level, where $80 \%$ of the species were replaced. The innovation maxima well coincided with the global sea-level high stands in the Silurian (see Johnson et al., 1991); the extinction maxima usually corresponded to the sea-level low stands (see Fig. 1).

In order to minimize the influence of the time factor upon the interpretation of the chitinozoan diversity dynamics, the total rate, i. e. the number of the appearances and disappearances of species per one million years (Fig. $5 A, B$ ) and the per taxon rate, i. e. the number of appearances and disappearances per chitinozoan species diversity (Fig. $5 C, D$ ) have been calculated for all graptolite zones (after Jones and Nicol, 1986). The approximate duration of the graptolite zones in million years (Myr) is given (Table 1) according to D. Kaljo (pers. comm.). 


\begin{tabular}{|c|c|c|c|c|c|c|}
\hline \multirow{2}{*}{$\frac{\omega}{5}$} & \multirow{2}{*}{$\frac{5}{5}$} & \multicolumn{2}{|c|}{ Regional units } & \multirow{2}{*}{$\begin{array}{l}\text { Graptolite } \\
\text { scale }\end{array}$} & Global sea level curve & \multirow{2}{*}{$\begin{array}{c}\text { Chitinozoan } \\
\text { biozones }\end{array}$} \\
\hline & & Stage & \begin{tabular}{|c|} 
Graptolite \\
biozones \\
\end{tabular} & & Shallow * & \\
\hline \multirow{3}{*}{$\frac{\bar{a}}{\frac{1}{2}}$} & & \multirow[t]{3}{*}{$K_{4}$} & \multirow[b]{4}{*}{ is } & \multirow{2}{*}{ lochkovensis } & & Urnochitina \\
\hline & & & & & & $\begin{array}{l}\text { E. filifera- } \\
\text { E. pistilliformis }\end{array}$ \\
\hline & & & & ultimus - & & A. fragilis \\
\hline \multirow{5}{*}{$\begin{array}{l}3 \\
0 \\
\vdots \\
\vdots \\
v\end{array}$} & \multirow{5}{*}{ 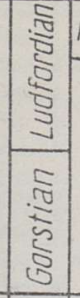 } & $\mathrm{K}_{3} \mathrm{a}$ & & formasus & & $\begin{array}{l}\text { S. sphaerocep/rala } \\
\text { C. granosa }\end{array}$ \\
\hline & & \multirow{4}{*}{$K_{2}$} & balticus & Neocucullograpt. & & $\begin{array}{l}\text { E. philipi- } \\
\text { E. lagenomorpha }\end{array}$ \\
\hline & & & tauragensis & \begin{tabular}{|l} 
leintwardinensis \\
tumescens \\
\end{tabular} & & C. latifrons \\
\hline & & & scanicus & scanicus & & G.militaris - C.sp.2 \\
\hline & & & nilssoni & nilssani & & Conochitina sp.1 \\
\hline \multirow{10}{*}{$\begin{array}{l}x \\
0 \\
0 \\
5 \\
0 \\
0 \\
3\end{array}$} & \multirow{4}{*}{\begin{tabular}{|c|}
$\frac{5}{5}$ \\
$\frac{0}{2}$ \\
$\frac{2}{2}$ \\
$\frac{1}{2}$
\end{tabular} \mid} & \multirow[t]{2}{*}{$K_{1}$} & ludensis & luctensis & & interzone $\underline{V}$. \\
\hline & & & massa & nassa & & S.indecora \\
\hline & & \multirow{5}{*}{$\mathrm{J}_{2}$} & testis & \multirow{2}{*}{ lundgreni } & & C.cribrosa \\
\hline & & & radians & & & C. subcyatha \\
\hline & \multirow{6}{*}{$\begin{array}{c}5 \\
5 \\
\frac{0}{5} \\
0 \\
0 \\
3 \\
5 \\
0 \\
5 \\
5\end{array}$} & & & \multirow{2}{*}{ ellesae } & & C. pachycephata \\
\hline & & & pelारा & & & E.lagena \\
\hline & & & flexilis & linnarssoni & & C. cingulata \\
\hline & & \multirow{3}{*}{$J_{1}$} & antennularius & rigidus & & C. tuba \\
\hline & & & riccartonensis & riccartonensis & & $\begin{array}{l}\text { C.Cf. mamanilla } \\
\text { interzone IV }\end{array}$ \\
\hline & & & $\begin{array}{l}\text { murchisani } \\
\text { Dohemicus }\end{array}$ & \begin{tabular}{|l} 
murchisoni \\
centrifugus \\
\end{tabular} & & M.margaritana \\
\hline \multirow{4}{*}{$\begin{array}{l}2 \\
2 \\
0 \\
0\end{array}$} & \multirow{4}{*}{$\frac{\sqrt{\frac{\pi}{2}}}{\frac{5}{2}}$} & \multirow{5}{*}{$H$} & spiralis & cremulata & & C.proboscifera \\
\hline & & & griestoniensis & griestoniensis & & A. longicallis \\
\hline & & & crispus & crispus & & 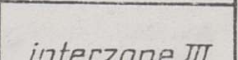 \\
\hline & & & turriculatus & turriculatus & & \\
\hline \multirow{6}{*}{$\begin{array}{l}0 \\
0 \\
\sigma \\
\theta \\
-v\end{array}$} & \multirow{3}{*}{$\begin{array}{l}\frac{5}{2} \\
\frac{0}{5} \\
0 \\
0 \\
0 \\
\square\end{array}$} & & sedgwickii & sedgwickii & & C.emmastensis \\
\hline & & \multirow{3}{*}{$G_{3}$} & canvolutus & Convolutus & & interzone II \\
\hline & & & gregarius & gregarius & & \begin{tabular}{|l|} 
C.cf.profracta \\
A. canvexa \\
\end{tabular} \\
\hline & \multirow{3}{*}{ 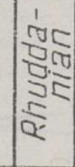 } & & cyphus & cyphus & & C. electa \\
\hline & & \multirow{2}{*}{$G_{1-2}$} & conferius & vesiculosus & & C.postrobusta \\
\hline & & & & acuminatus & & \begin{tabular}{|c|} 
interzone I \\
A. laevaensis \\
\end{tabular} \\
\hline
\end{tabular}

Fig. 1. Correlation of the East Baltic graptolite and chitinozoan biozones with the Silurian standard graptolite scale (according to Решения..., 1987). Global sea-level curve after Johnson et al. (1991). Regional stages: $G_{1-2}-$ Juuru, $G_{3}-$ Raikküla, $H-$ Adavere, $J_{1}-$ Jaani, $J_{2}-$ Jaagarahu, $K_{1}-$ Rootsiküla, $K_{2}-$ Paadla, $K_{3} a-$ Kuressaare, $K_{3} b-$ Kaugatuma, $K_{4}-$ Ohesaare. 


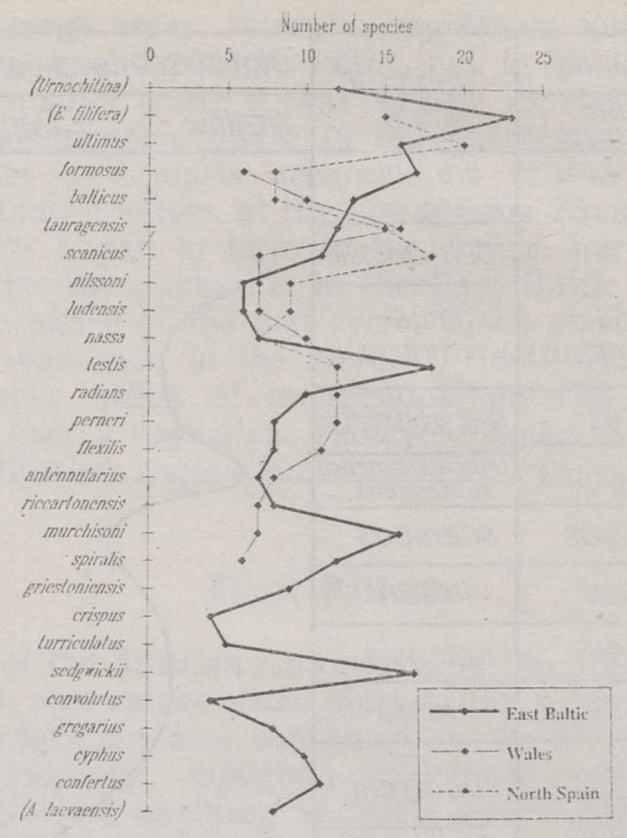

Fig. 2. Chitinozoan species diversity curves, plotted in the middle of each graptolite zone. Where graptolites were not established, chitinozoan biozones were used (in brackets).

Innovatioa . \%

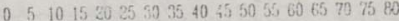

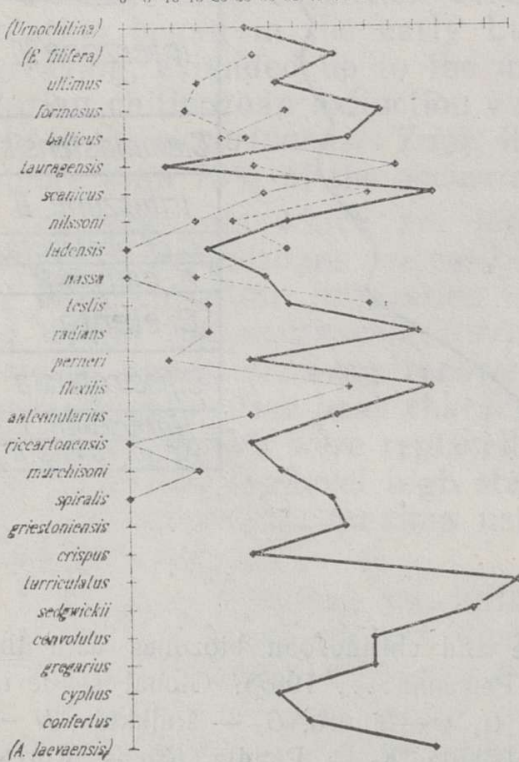

Fig. 3. Chitinozoan innovation curves. For legend see Fig. 2.
Extinction , \%

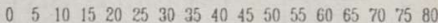

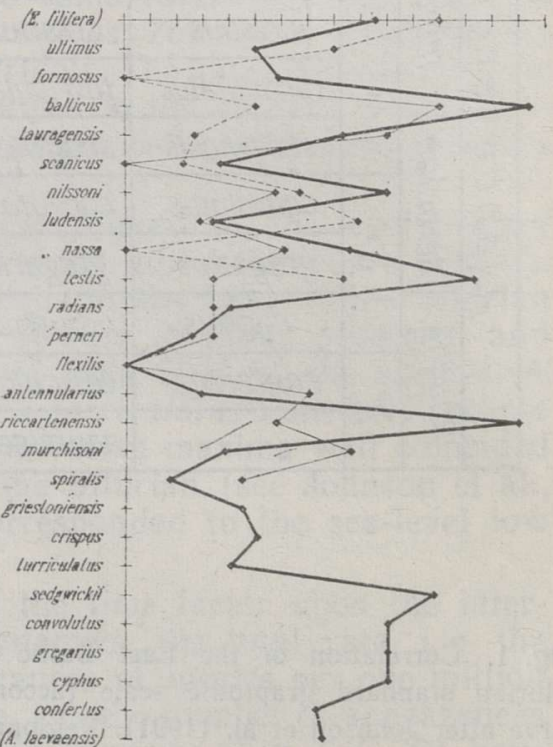

Fig. 4. Chitinozoan extinction curves. For legend see Fig. 2. 
Total rate: appearing species per 1 Yyr

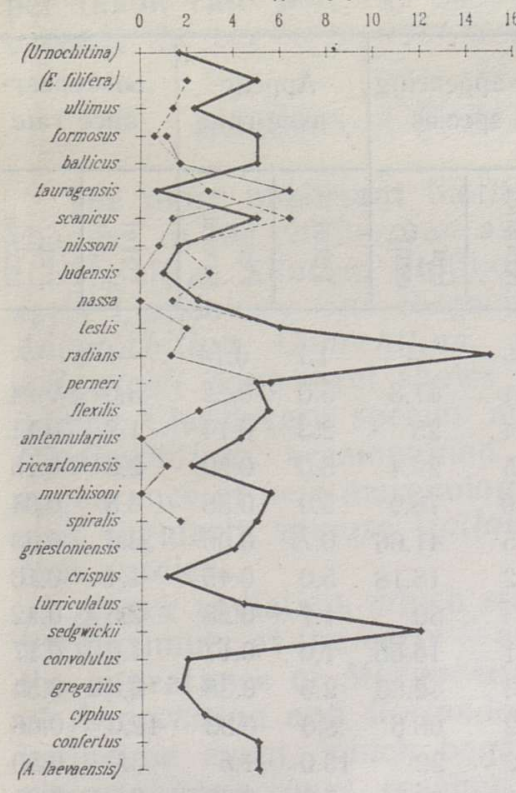

C

Per taxon appearance rate

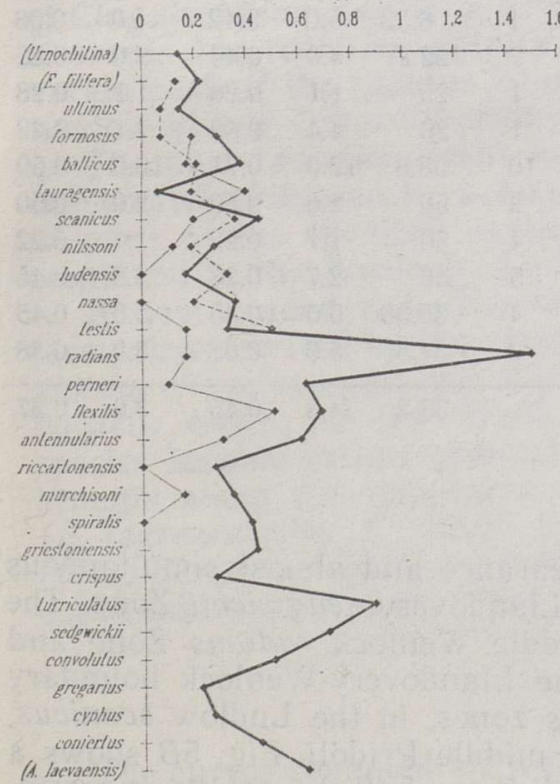

Total rate: disappearing species per 1 Mỳr $\begin{array}{lllllllllllll}0 & 1 & 2 & 3 & 4 & 5 & 6 & 7 & 8 & 9 & 10 & 11 & 12\end{array}$

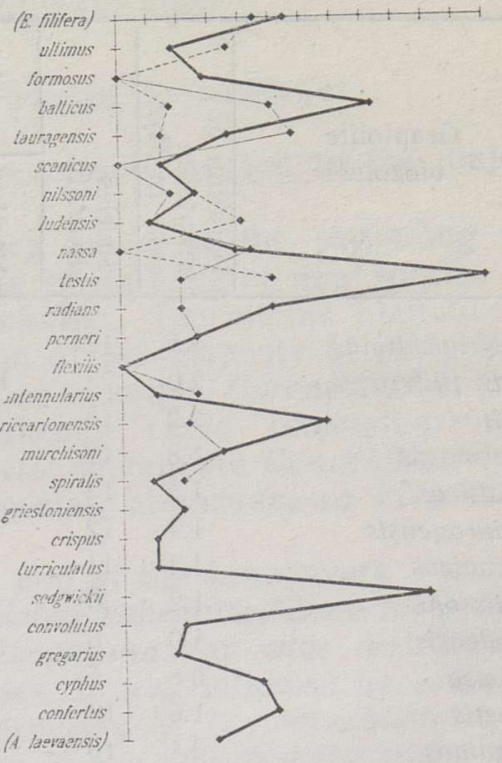

$D$

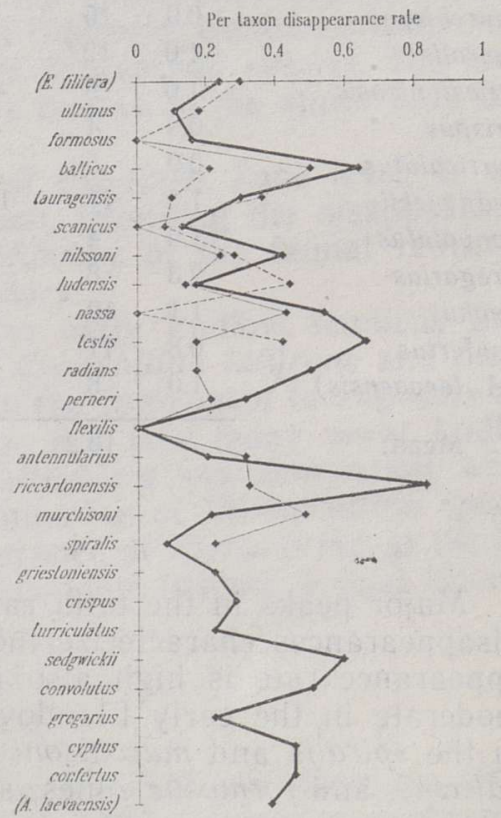

Fig. 5. Total appearance and disappearance rates of chitinozoan species per one million years $(A, B)$. Per taxon appearance and disappearance rates of chitinozoan species per one million years per total species diversity $(C, D)$. 


\section{Numerical data for the East Baltic chitinozoan species diversity curves (Figs. 2-5)}

\begin{tabular}{|c|c|c|c|c|c|c|c|c|c|c|}
\hline \multirow{2}{*}{$\begin{array}{l}\text { Graptolite } \\
\text { biozone }\end{array}$} & \multirow{2}{*}{ 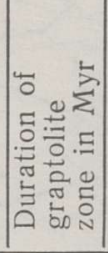 } & \multirow{2}{*}{ 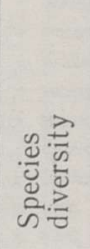 } & \multicolumn{2}{|c|}{$\begin{array}{l}\text { Appearing } \\
\text { species }\end{array}$} & \multicolumn{2}{|c|}{$\begin{array}{c}\text { Disappearing } \\
\text { species }\end{array}$} & \multicolumn{2}{|c|}{$\begin{array}{l}\text { Appear- } \\
\text { ance rate }\end{array}$} & \multicolumn{2}{|c|}{$\begin{array}{l}\text { Disappear- } \\
\text { ance rate }\end{array}$} \\
\hline & & & 总 & 它 & 蒠 & 它 & $\stackrel{\pi}{0}$ & 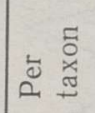 & 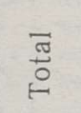 & 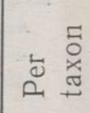 \\
\hline (Urnochitina) & 1.8 & 12 & 3 & 25 & - & - & 1.7 & 0.14 & - & - \\
\hline (E. filifera) & 2.0 & 23 & 10 & 43.47 & 11 & 47.8 & 5.0 & 0.22 & 5.5 & 0.24 \\
\hline ultimus & 2.2 & 16 & 5 & 31.25 & 4 & 25 & 2.3 & 0.14 & 1.8 & 0.11 \\
\hline formosus & 1.8 & 17 & 9 & 52.9 & 5 & 29.4 & 5.0 & 0.29 & 2.8 & 0.16 \\
\hline balticus & 1.2 & 13 & 6 & 46.15 & 10 & 76.9 & 5.0 & 0.38 & 8.3 & 0.64 \\
\hline tauragensis & 1.4 & 12 & 1 & 8.33 & 5 & 41.66 & 0.7 & 0.06 & 3.6 & 0.30 \\
\hline scanicus & 1.4 & 11 & 7 & 63.6 & 2 & 18.18 & 5.0 & 0.45 & 1.4 & 0.13 \\
\hline nilssoni & 1.2 & 6 & 2 & 33.3 & 3 & 50 & 1.7 & 0.28 & 2.5 & 0.42 \\
\hline ludensis & 1.0 & 6 & 1 & 16.66 & 1 & 16.66 & 1.0 & 0.17 & 1.0 & 0.17 \\
\hline nassa & 0.8 & 7 & 2 & 28.57 & 3 & 42.85 & 2.5 & 0.36 & 3.8 & 0.54 \\
\hline testis & 1.0 & 18 & 6 & 33.3 & 12 & 66.6 & 6.0 & 0.33 & 12.0 & 0.66 \\
\hline radians & 0.4 & 10 & 6 & 60 & 2 & 20 & 15.0 & 1.5 & 5.0 & 0.50 \\
\hline perneri & 0.4 & 8 & 2 & 25 & 1 & 12.5 & 5.0 & 0.63 & 2.5 & 0.31 \\
\hline flexilis & 0.9 & 8 & 5 & 62.5 & 0 & 0 & 5.5 & 0.69 & 0 & 0 \\
\hline antennularius & 0.7 & 7 & 3 & 42.85 & 1 & 14.28 & 4.3 & 0.61 & 1.4 & 0.20 \\
\hline riccartonensis & 0.9 & 8 & 2 & 25 & 6 & 75 & 2.2 & 0.28 & 6.7 & 0.83 \\
\hline murchisoni & 0.9 & 16 & 5 & 31.25 & 3 & 18.75 & 5.6 & 0.35 & 3.3 & 0.21 \\
\hline spiralis & 1.0 & 12 & 5 & 41.66 & 1 & 8.33 & 5.0 & 0.42 & 1.0 & 0.08 \\
\hline griestoniensis & 1.0 & 9 & 4 & 44.4 & 2 & 22.2 & 4.0 & 0.44 & 2.0 & 0.22 \\
\hline crispus & 0.9 & 4 & 1 & 25 & 1 & 25 & 1.1 & 0.28 & 1.1 & 0.28 \\
\hline turriculatus & 0.9 & 5 & 4 & 80 & 1 & 20 & 4.4 & 0.89 & 1.1 & 0.22 \\
\hline sedgwickii & 1.0 & 17 & 12 & 70.58 & 10 & 58.8 & 12.0 & 0.71 & 10.0 & 0.59 \\
\hline convolutus & 1.0 & 4 & 2 & 50 & 2 & 50 & 2.0 & 0.50 & 2.0 & 0.50 \\
\hline gregarius & 2.3 & 8 & 4 & 50 & 4 & 50 & 1.7 & 0.22 & 1.7 & 0.22 \\
\hline cyphus & 1.1 & 10 & 3 & 30 & 5 & 50 & 2.7 & 0.27 & 4.5 & 0.45 \\
\hline confertus & 0.8 & 11 & 4 & 36.36 & 4 & 36.36 & 5.0 & 0.45 & 5.0 & 0.45 \\
\hline (A. laevaensis) & 1.0 & 8 & 5 & 62.5 & 3 & 37.5 & 5.0 & 0.63 & 3.0 & 0.38 \\
\hline Mean: & & 10.2 & & 42.2 & & 35.2 & 4.3 & 0.45 & 3.6 & 0.37 \\
\hline
\end{tabular}

Major peaks in the total rate of appearance and almost simultaneous disappearances characterize the middle Llandovery sedgwickii Zone. The appearance rate is high also in the middle Wenlock radians Zone and moderate in the early Llandovery, at the Llandovery-Wenlock boundary in the spiralis and murchisoni bohemicus zones, in the Ludlow scanicus, balticus, and formosus zones, and in the middle Pridoli. Fig. $5 B$ shows a high disappearance rate for the sedgwickii Zone, but also for the riccartonensis, testis, balticus zones and for the middle Pridoli. Lower rates of disappearance characterize the lowermost middle Llandovery, the Wenlock antennularius, flexilis, nassa, and ludensis zones, the lower Ludlow and the Pridoli ultimus Zone.

The positions of the appearance and disappearance peaks in the per taxon rate plots (Fig. $5 C, D$ ) are similar to those on the total rate charts. The main differences concern the sedgwickii and turriculatus zones. 
The total appearance rate is very high at the sedgwickii Zone level, but considerably lower within the turriculatus Zone. At the same time, in the per taxon rate plot the appearance rate at the turriculatus Zone level exceeds the per taxon rate seen in the sedgwickii Zone.

\section{Relations of Events with Chitinozoan Assemblages}

The most important biotic events were closely related to the major changes in the chitinozoan assemblages.

The first Silurian chitinozoan radiation event at the beginning of early Llandovery was characterized by the appearance of new species of Ancyrochitina, Conochitina, and Coronochitina. The middle Llandovery sedgrickii Zone level shows the extinction of the majority of early and middle Llandovery species and genera, for example Coronochitina and Cyathochitina, accompanied by simultaneous rapid innovation and appearance of new morphological characters: mucronate Conochitina species, regularly spinose Gotlandochitina species, abundance of Eisenackitina species.

A new radiation, which started at the end of the Llandovery, reached its maximum at the early Wenlock murchisoni bohemicus Zone level with the appearance of Margachitina and Anthochitina and wide distribution of Angochitina and Gotlandochitina species. It was followed by a major extinction event, which began at the boundary of the murchisoni and riccartonensis zones, reached its maximum in the mid-riccartonensis, and was characterized by the disappearance of most of the late Llandovery and early Wenlock species, dominated by Conochitina proboscifera.

A new innovation high stand was attained at the middle Wenlock flexilis Zone level and characterized by the appearance and abundance of Cingulochitina cingulata, Clathrochitina clathrata, Gotlandochitina martinssoni, Ancyrochitina gutnica, and other widespread species. The innovation peak of the radians Zone is mainly related to the appearance of a number of new Conochitina species.

The next radiation event took place at the testis Zone level. It was immediately followed by a major extinction, involving the disappearance of most of the Wenlock species. The tendency of the faunal reduction continued at the Wenlock-Ludlow boundary.

A new graded radiation began at the early Ludlow scanicus Zone level, characterized by the appearance of Conochitina latifrons and Angochitina elongata at the end of this zone. In the subsequent tauragensis and balticus zones, the last Wenlock species, but also many early Ludlow species became extinct gradually. This initiated a new innovation, which brought along the reappearance and domination of Eisenackitina species (E. lagenomorpha, E. philipi, etc.), appearance of Pterochitina at the formosus Zone level and Fungochitina in the middle Pridoli. A final Silurian extinction started in the late Pridoli.

\section{Comparison}

The curves compiled for the East Baltic, Welsh Basin (Dorning, 1981), and Palencia, North Spain (Schweineberg, 1987) permit to make some comparisons between these areas (see Figs. 2-5, Tables 1 and 2).

The relative diversity and dynamics of chitinozoan species from the other two regions are comparable to the East Baltic only in general trends. The specific diversity increases gradually towards the middle Wenlock (in Wales) and decreases in the latest Wenlock, being low at the Wenlock-Ludlow boundary zones. Diversity is high again in the middle Ludlow, lowering in the topmost Ludlow. In the early Pridoli a new 
diversity high stand followed (in North Spain). The major chitinozoan innovation occurred at the levels of the flexilis and scanicus zones; major extinction events have been recorded in the testis, nilssoni, and balticus zones and in the middle Pridoli.

Below some comparisons of chitinozoan and graptolite dynamics (after Koren, 1987) will be outlined. The most prominent graptolite diversity peak is assigned to the gregarius Zone, but chitinozoans at this level are already loosing their relatively high diversity, occurring in the confertus and cyphus zones. The mass extinction event took place at the riccartonensis Zone level, involving both groups. Also the major radiation events coincide in the lundgreni (testis) Zone, followed immediately by drastic mass extinction in the topmost part of the zone. The early and late Ludlow graptolites show two well-pronounced diversity peaks in the scanicus and formosus zones and one smaller maximum occurs in the middle Pridoli. An analogous picture can be seen in the chitinozoan innovation chart.

Table 2

Numerical data for the diversity curves of the Welsh Basin $(A)$ and North Spain $(B)$ chitinozoan species (Figs. 2-5)

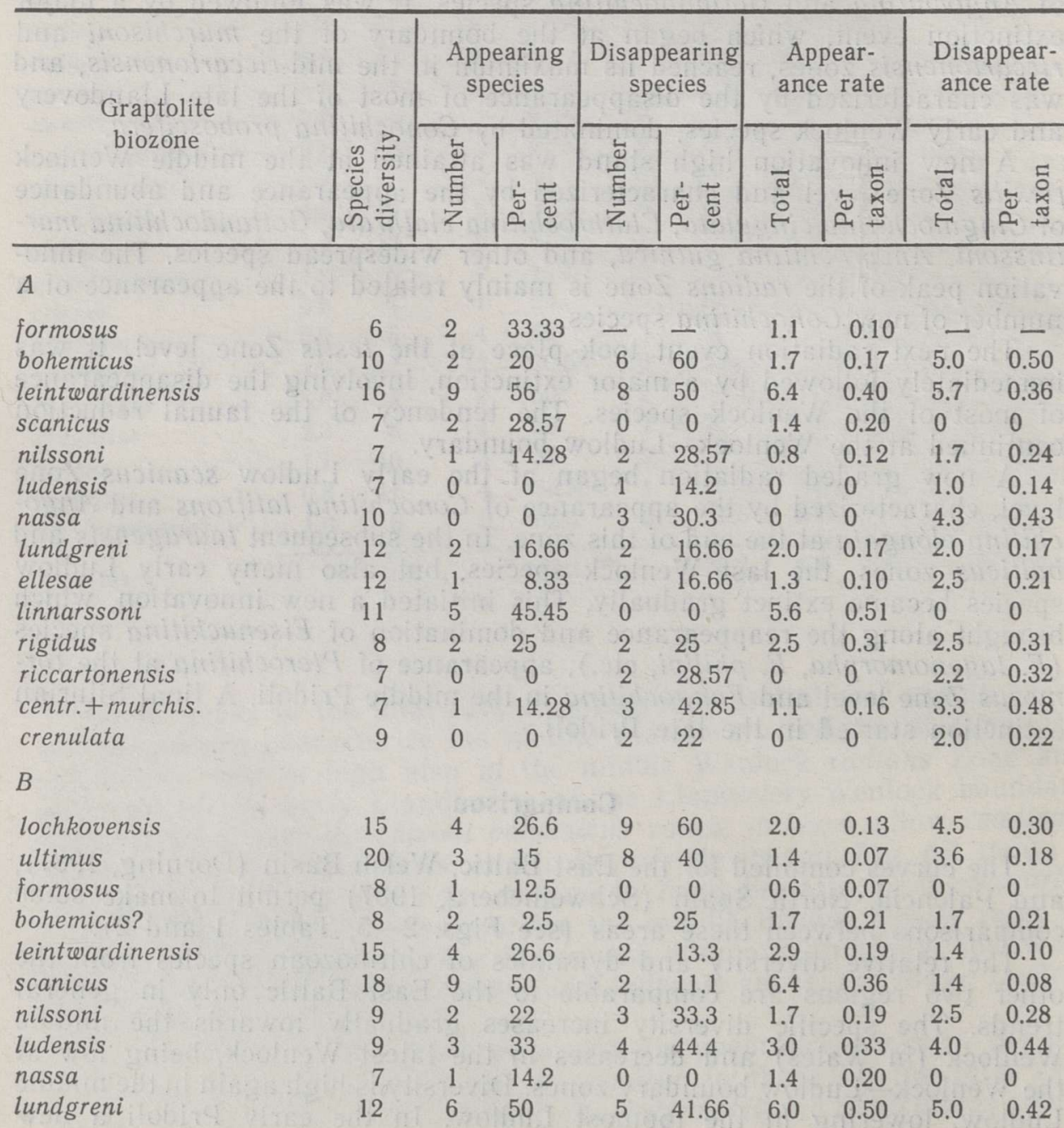




\section{Conclusions}

1. Chitinozoan dynamics, i. e. their major innovation and extinction events were in good correlation with the transgression-regression phases of the Silurian Baltic Basin and with the global sea-level changes.

2. The maxima of different chitinozoan bioevents are close or coincide in most of the charts and occur at the sedgwickii, riccartonensis, radians, testis, scanicus, balticus, and formosus zones. These levels may serve as time markers for the global correlations.

3. The most important bioevents in chitinozoan dynamics during the Silurian were closely related to the evolutionary changes in the chitinozoan assemblages.

4. The prominent East Baltic chitinozoan radiation and extinction peaks show good correlation with the Silurian graptolite diversity and extinction maxima of other regions.

5. The fluctuations of the East Baltic Silurian chitinozoan diversity are not entirely concordant with those of Wales and North Spain, but comparable in general trends.

Acknowledgements. My thanks are due to Prof. D. Kaljo for many helpful suggestions, to Anne Noor for linguistic help, and Kaur Nestor for computer graphics.

\section{REFERENCES}

Dorning, K. J. 1981. Silurian Chitinozoa from the type Wenlock and Ludlow of Shropshire, England. - Rev. Palaeobot. Palynol., 34, 205-208.

Johnson, M. E., Kaljo, D., and Rong, J.-Y. 1991. Silurian eustasy. - In: M. G. Bassett, P. D. Lane, and D. Edwards (eds.). The Murchison Symposium. Special Papers in Palaeontology, 44, 145-163.

Jones, D. S. and Nicol, D. 1986. Origination, survivorship and extinction of rudist taxa. - J. Paleont., 60, 107-115.

Kaljo, D. 1971. The tectonic factor in the geological history of the East Baltic Basin during the Silurian. Colloque Ordovicien-Silurien, Brest, September 1971. Mémoires du B. R. G. M., 73, 275-279.

Koren, T. N. 1987. Graptolite dynamics in Silurian and Devonian time. - Bull. Geol. Soc. Denmark, 35, 149-159.

Nestor, V. 1990. Silurian chitinozoans. - In: D. Kaljo, H. Nestor (eds.). An Excursion Guidebook. Tallinn, 80-83.

Nestor, V. and Nestor, H. 1991. Dating of the Wenlock carbonate sequences in Estonia and stratigraphic breaks. - Proc. Estonian Acad. Sci. Geol., 40, 2, 50-60.

Schweineberg, J. 1987. Silurische Chitinozoen aus der Provinz Palencia (Kantabrisches Gebirge, N-Spanien). - Göttinger Arb. Geol. Paläont., 33, 1-94.

Кальо Д. Л. 1970. Граптолиты. - In: Силур Эстонии. Таллинн, Валгус, 179-184.

Решения Межведомственного стратиграфического совещания по ордовику и силуру Восточно-Европейской платформы 1984 г. с региональными стратиграфическими схемами. 1987. Ленинград, 1-114.

Ульст Р. Ж. 1987. Распространение граптолитов в венлокских и лудловских отложениях скв. Вентспилс-Д3. - In: Л. К. Гайлите, Р. Ж. Ульст, В. И. Яковлева. Стратотипические и типовые разрезы силура Латвии. Рига, Зинатне, $129-136$.

Эйнасто Р. Э. 1986. Основные стадии развития и фациальные модели силурийского краевого бассейна Балтики. - In: Д. Л. Кальо, Э. Р. Қлааманн (eds.). Теория и опыт экостратиграфии. Таллинн, $37-54$. 
Viiu NESTOR

\section{KITINOZOADE MITMEKESISUSE DUNAAMIKA IDA-BALTI SILURIS}

Kitinozoade liigiline mitmekesisus on siluri kestel pidevalt muutunud, Liikide arvukust on analüüsitud graptoliidi skaala alusel. Olulisemaid liikide ilmumise ja kadumise tasemeid on vaadeldud biosündmustena, mis ei ole tihedalt seotud mitte ainult grupisiseste evolutsiooniliste muutustega, vaid ka Balti basseini transgressiooni- ja regressioonifaaside ning globaalsete merepinna kõikumistega.

Buйy HECTOP

\section{ДИНАМИКА РАЗНООБРАЗИЯ ХИТИНОЗОЙ В СИЛУРЕ ПРИБАЛТИКИ}

Видовое разнообразие хитинозой в силуре Прибалтики постоянно изменялось. Численность видов анализируется по региональной граптолитовой шкале. Наиболее массовые появления и исчезновения видов на определенных уровнях рассматриваются как биотические события, которые связаны не только с эволюционными изменениями внутри группы, но и с фазами трансгрессии и регрессии Балтийского бассейна и колебаниями уровня мирового океана. 